\title{
MOTIVATION OF YOUNG IT PROFESSIONALS
}

\author{
Svetlana Gribanova ${ }^{1}$, Anna Abeltina ${ }^{2}$ \\ Faculty of Business Admistration, Turiba University, Graudu 68, Riga, Latvia

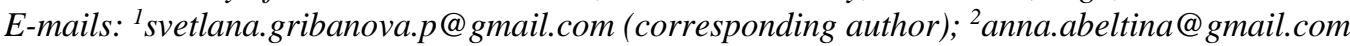

\begin{abstract}
The research answers the following question: what actions do organizations undertake to attract and retain young IT professionals and how do they correspond with expectations of young IT specialists? In order to get information about life values of young professionals, their expectations and apprehensions, in this research qualitative methodology and semi-structured interview method were used.

All the respondents were conditionally divided in accordance to the companies they are employed with into international companies, big Latvian companies and modern IT companies. The research showed that different types of companies use different strategies to attract, retain and motivate young IT specialists. International companies try to satisfy the needs of young professionals for self-expression, freedom and self-realization. Big Latvian companies try to create environment where employees feel their dependence from the organization and are afraid to lose their jobs. Modern IT companies shape attachment to the company and create desire to make this company more competitive.
\end{abstract}

Keywords: motivation, IT professionals, young generation, Latvia, values.

JEL Classification: M12, M15, O15.

\section{Introduction}

The effective motivation model needs to be created in order to achieve corporate goals. The motivation process needs to correspond with employee value system and needs life goals. The need in life goals which are tightly connected with the shift from survival to self-expression values discussed in Modernization Theory demonstrate the importance of correct and well-developed motivation system for attracting and further retaining employees.

All theories of motivation can be relatively split into three groups: theories which observe motivation as a way of satisfying needs of employees (Alderfer, 1972; Maslow, 1954; McClelland \& Burnham, 1976; Inglehart \& Welzel, 2005); theories, which describe motivation as a process which leads to successfully functioning organization (Herzberg, 1987; Herzberg, Mausner, \& Snyderman, 2010; Kopelman, Prottas, \& Falk, 2012; McGregor, 1960) and theories, where motivation can be considered as interactive process between society and individual, where organization is an intermediary of this process (Bourdieu, 1996; Trigg, 2004).

It is quite clear that motivation of employees leads any organization to higher output level. It perfectly corresponds with the engagement theory that states that an employee that has a positive attitude towards goals and values of the organization is very beneficial for the company. This is why company should create the participative working environment that stimulates engagement of employees (Kahn, 1990).

Many authors state that human resources are most valuable source of any organization (Llaci, 2010; Pfeffer, 1994), so understanding what makes people hold in particular organization makes sense for any kind of their professional field. Shoraj and Llaci (2015) have conducted a relevant survey on how elements of motivation work and influence on business orgaizations' outputs in modern Albania.

In order to enhance motivation big organizations with several levels of management may use internal transitions as an instrument for better motivation, but 'little is known about when and why internal transitions actually enhance employees' engagement and reduce their turnover intentions.' (Verbruggen, Cooman, \& Vansteenkiste, 2015). The key idea for effective motivation may be in differentiating between transition challenges and transition hindrances for individuals inside organizations. The investment in education and health level of workers gives modern organizations extra competitive advantages because their human resources become more stable and effective (Lado 
\& Wilson, 1994). But we must be aware that some workers are motivated mostly by intrinsic (e.g., technology enhanced learning at workplace, more interesting job tasks) another by mostly extrinsic (e.g., higher salary) rewards (Bidwell \& Mollick, 2014; Deci, 1975; Feldman \& Ng, 2007; Ryan \& Deci, 2000a) when they decide about internal transition as a way of their social development. The variety of approaches to motivation and practical tools of motivating employees determines the necessity to view motivation within the organization as a system. Motivation system can be defined as combination of tools and methods that is conscript to motivate employees within the organization.

So we can hypothesize that the motivation of employees may strongly depend on opportunities that they see in their workplaces. A possibility to improve level of employee's education also treated as a motivational factor, and on another side some studies are concluding about importance of "manager, colleague" and another kinds of support for those who starts learning in current professional field. If support is coming a worker is more likely continuing education (Park \& Choi, 2009), consequently a worker that supported by company while getting education will stay loyal and will be satisfied by his workplace (Naujokaitiene, Tereviciene, \& Zyudzinaite, 2015). The background characteristics of workers as age, education, nationality, gender, social patterns also must be taken into account while making a good motivation tools for companies in ITfield. For better application of interview methods some authors (Ji, Anderson, \& Wu, 2016) use "self-determination theory", which studies workers' motivations by exploring their interpretation of why they selected their current occupation (Ryan \& Deci, 2000b). There some hints for exploration of extrinsic motivation on work performance in Hildebrandt and Eom's (2011) work with age properties taken into account. It was found that 'position promotion, increase of salary, and recognition from others are important extrinsic motivational factors to school teachers'. Allen and May (2017) have applied social psychology, particularly translational mobilization theory (TMT) for studying socially constructed objects at several scales.

In our article we use interviews for understanding motivational factor among young IT professionals. Ji et al (2016) found out that "there are no one-size-fits-for-all mechanisms to motivate" personnel. Our goal is to understand what factor of motivating young professional would hold people under their 30ies to stay in country or come back to homeland as well.

\section{Methodology}

The aim of the research is to study opinion of young professionals of information technologies on what tools the organizations use in order to attract and motivate them to work in these companies.

The main research question is: what actions do organizations undertake to attract and retain young IT professionals and how they correspond with expectations of young IT specialists?

In order to get information about life values of young professionals, their expectations and apprehensions, in this research qualitative methodology and semi-structured interview method were used.

Initially the idea of the qualitative research was to make a series of semi-structured interviews of HR specialists who work in the organizations which employ IT professionals and IT professionals separately. The aim of interviewing HR professionals was to find out more about strategies and tools organizations use to attract and retain young IT professionals. However, after contacting several organizations and HR specialists directly the author was informed that HR specialists operate under the privacy agreement and they are not allowed to discuss strategies organizations use. Therefore, the author had to include in the semistructured interviews with IT professionals questions about what the organizations they are employed in do in order to attract, retain and motivate employees, what traditions employees have and how organizations support young professionals. Due to the specifics of the occupation several IT professionals were interviewed via Skype and others in person. On one hand, this approach is subjective as the above is described from the point of view of employees and does not state official strategy proclaimed by the company. But in the other hand, employees point out the most significant, valuable and applied in reality ways of motivating, retaining and attracting employees. So in fact, these are actions which are brought to life by the management, remembered and appreciated by employees, but not the ones which are described on the paper or discussed in the meetings but not implemented in reality.

The usage of interviews as a method of conducting the research is justified by the necessity to 
receive comprehensive answers, understand the situation in details. In comparison to other tools, such as surveys, semi-structured interviews assume more freedom both to interviewer and respondents.

In the framework of this research the sampling of maximum variation was used. This strategy of shaping target-oriented samples is directed towards description of the central aspects which cover major part of all cases. In this research in order to build-up the samples the authors tried to maximally diversify such parameters as place of getting higher education, age, family experience, gender and belonging or not belonging to titular ethnic group. From this point of view, all these parameters influence the decision-making of professional strategies, work satisfaction and loyalty to the company. In such a manner in the sampling young professionals who educated both in Latvia and abroad, males and females, married and single, having experience in working abroad and not having such experience, were included in sample.

The attempt to provide sufficient variety at moderate sample size can cause some problems, because individual cases differ from each other dramatically. Sampling strategy, based on the maximal variation turns this weakness into strength with the help of the following logics: every model, which appears from big variety of cases, is of special interest and value in researching the main topics of the research.

In the situation when the researcher decides to use in his research sample, which was received with the method of maximal variation, data collection and its analysis has to involve two points: detailed description of every case of high quality, which might be useful due to its uniqueness; description of important general model appearing in several (or all) cases. This was done during interview analysis.

The search of the respondents was done with the help of the snowballing method. This approach, as a rule, is used in order to determine key informants, who after the interview with them is done, are asked to recommend someone with some definite parameters for further contact. In such a way within sight of the researcher more new candidates appear and "snow ball" becomes bigger and bigger. Nevertheless, in most cases every time only several names or cases will be called. Special attention is paid to those individuals who are recommended as the most valuable by different informants.

In this research the criteria of theoretic filling was used as well, and it appeared at the sample size of 18 interviews. After that 2 more respondents were interviewed and they just confirmed the conclusion done. In such a way, the sample size is 20 people.

Following the motivation theories used in this research mostly the tools of motivation can be spread into two major groups: the ones which are material ones and the non-material factors. Therefore respondents were asked what except salary their organization does for them, what they would like to add to the current strategy of their organization.

In the framework of tools and strategies of the organizations reviewed in the introduction respondents were more asked about types of support their organization has to offer for them, if they agree with current schedule or they prefer more freedom in choosing working hours or vacation time. They were also asked about traditions in their company in order to understand what other tools organization do or do not use in order to familiarize employee with the company.

\section{Strategies, motivations and values: analysis of semi-structured interviews with young professionals}

The young IT professionals' interview analysis allows to bring to light their life values, expectations from work and profession they have chosen and also their conceptualization of how the companies have to support young professionals.

The sampling was formed based on the principle of maximum variation in order to include people with various biographies. That is why generally young IT professionals are very different as well as in their values, needs, expectations and in life and working conditions. In the sample there were questioned married and unmarried respondents, respondents with and without children, respondents who have managerial position and respondents who are general employees, respondents who own their own place of living and respondents who rent, live with parents or pay mortgage. All the above factors influence deeply on the structure of needs of young professionals as the needs are formed not only from values but also from real-life situation. Therefore during the creation of effective employee motivation strategy it is necessary to create a set of different and flexible solutions so every employee can be covered by this strategy and benefit on it.

During interview analysis the authors have tried to determine the ways of attracting and retaining of young IT professionals on Latvian labor 
market as well as analyze values young professionals have. This interest is mostly connected with the fact that effective strategies of organizations are possible only in the case if they correspond with values and expectations professionals have.

The ways how contemporary companies motivate people to work differ. It is possible to divide companies into several groups according to the strategies they use in order to motivate the employees. The first group which can be defined includes international companies which have their branches in Latvia: they employ more than 200 employees and are considered according to the interviewer respondents "big players" or leaders in the area they operate in.

\subsection{Ways of motivation and strategies in international companies}

Respondents, who work in international companies having branches in Latvia, mention that in such companies the attitude towards specialists is very loyal. The research results allow forming out two strategies, which international companies use in order to shape young professionals' loyalty: using material factors and using of non-material factors. In this case for the research it is important the understanding of how both material and non-material factors influence shaping loyalty towards the company.

Material factors can include high salary, good insurance program, and possibility of business trips, additional benefits to gain for welldone job and financial coverage of professional development courses.

The salary in international companies is, as a rule, higher than average salary on the IT market. On top of that the salary in the international companies does not depend on work experience as much as it depends on the work which has to be done. Exactly this attracts young professionals to these companies. Many respondents answering the question about salary admitted that their salary is good: "Salary, I think, is good" (Rolands).

Medical insurance provision can be also treated like addition to the salary. If the company provides it, respondents always underline this fact as an important working condition: "There is also insurance" (Rolands), "Insurance is given for an employee for a year and then is prolonged" (Ruslans).

Financial coverage of business trips to other countries is also important for young professionals not as material privilege or benefit but as an opportunity of career development, communication with colleagues from abroad and experience exchange. "It is possible to go to business trips to different countries such as Sweden, Netherlands, Lithuania, Estonia" (Rolands). Employees are also informed and aware of the opportunities of career growth, they know that they can try themselves on new positions: "it is not limited, you can grow and grow" (Rolands); "you can become team-lead, manager, project manager [..] there can be new projects when you can show a proper spirit” (Oleg).

Material bonuses as well as financial coverage of career development courses are considered by young professionals as significant advantage of working in international company. These organizations pay for English language courses, programming courses, management courses and courses, which help to improve personal business skills. Companies provide opportunities to improve qualification by attending courses or organizing these courses on the base of their own facilities: "Paid English courses, programming course, team-lead courses, manager's courses [..] programming, testing courses” (Rolands), "Company pays courses for qualification improvement for definite amount of money" (Oleg), "Sometimes company sends me to courses"(Ruslans).

The research results demonstrate that with the help of material factors international companies not only shape loyalty of their employees but also invest in their human capital. Investing in human capital increases competitiveness of the employees on the labor market, develop IT market and creates advantageous environment for further development. Employees with high qualification are oriented on creative, professional work (which international companies are ready to provide) in a first place instead of work which offers high salary. In such a way using strategies of investing in human capital, international companies not only shape their employees' loyalty but also create workforce oriented on working in this exact sector.

To non-material factors which are used by international companies in order to shape loyalty based on the results of the research can be referred the following ones: opportunity of remote work access, organization of employee leisure activities and creating attractive friendly environment in the organization.

Employees are allowed to work remotely if needed: "from home, from woods. Where is coverage, it is possible to work" (Rolands) especially 
in conditions of sickness or other circumstances which make presence at the office difficult: "if you are sick or by some reason cannot come, there is a possibility to connect remotely and work [..] this is very loyal, very flexible” (Oleg). This citation demonstrates that the opportunity of remote work is not just convenient for the employees but also profitable for the organization. The amount of working days lost due to illness of the employees is reduced as well as the amount of days lost due to personal circumstances.

Very significant stimulating factor for young employees is cooperative celebration not only of generally accepted holidays but also professional achievements tied with the end of big projects.

Employees are rewarded with both material (bonuses) and non-material benefits (celebration dinner, barbecue) for good job done: "after huge releases we had celebration in office" (Rolands).

On top of that companies arrange professional competitions, where victory is highly rewarded, for example "nomination "employee of the year" [..] a coupon for trip worth 2000 Euro" (Oleg), "yearly bonuses payouts" (Ruslan).

In such a way using material and non-material factors for shaping loyalty to the organization, international companies strengthen spirit of competitiveness in their environment, discovering and awarding the development of different business skills of the employees. However the research results demonstrate that development of competitiveness spirit combines with development of informal relationships and formation of friendly atmosphere in the companies. Companies organize different events for the whole team of employees in order to keep their informal communication active not only during working hours but also on weekends or after work: "there were many team events. And it is very important[..]we went from offices somewhere for a day-two, for example ride on boats, to sauna and so on, closer to nature”(Rolands), “ [... we also take part in city events[..] (Ruslans)”, “All employees are invited for two days and there is a huge feast " (Oleg);

Companies try to create friendly environment and atmosphere for employees, promote good relationship with management: "[...]it is not important who you are a tester or highest boss. You are on the same level and any time you can come to manager from Sweden, tip him on the shoulder and ask how he is doing” (Rolands).

The other way is to motivate current employees to attract new specialists by awarding them for it with special bonuses after the new specialist has passed probationary period and company is satisfied with this candidature: "If you attracted some of your friends and he passed probation period, you get a bonus for bringing this employee “ (Oleg).

It is very visible that the material motivation here is in minority. Of course even for organizing different events and courses resources are needed but as direct material motivation we can only consider bonuses and competitive salary. This situation is very alike the one which Herzberg described in his works, telling that material motivation can be the reason of employee dissatisfaction but the reason of employee satisfaction should lay in different dimension and be based on different approach. Herzberg pointed out how important for employees are mentorship, good relationship and support with colleagues, opportunities to develop and study. It is obvious that big international companies understand this and try to attract specialists not only with salaries but also retain them at work thanks to good relationship in the team, interesting events and earning opportunities stimulating employee satisfaction on a daily basis. "Salary is on 2nd-3rd place for me. My relationship with colleagues is on the first place" (Rolands), "There are two policies: boss and leader. "Boss" policy I consider as outdated not needed at all. [..] In IT sphere there has to be leader position. In order to have support. So the worker has the opportunity to come to manager or team-lead, communicate, share own dissatisfactions and ideas. [..] Relationships play very important role" (Oleg). And even considering the option of leaving the job or country, employees of the companies with such strategy of attracting and retailing personnel are not only unafraid to speak about this with their current management but consider the opportunity to go back to their job after this experience abroad is over for them: "Go back to Latvia, back to "T" (company name), but on higher position” (Rolands).

It is necessary to mention that the employees interviewed for this research who work in such companies belong to younger part of our young professional age definition (25-30). They are not older than 27. It is possible to assume that such strategy attract young dynamic people as it does not allow they to feel bored, demonstrates that company cares about them, gives them an opportunity to enjoy communication with like-minded people and even to have fun to some extent.

The employees of the international companies have good education and, as a rule, they have 
study or work experience abroad. For these people postmodern values are indicative: values of selfexpression, self-realization and freedom. It is hard to retain such employees only with the help of high salary. They are ready to change not only working place, but place of living as well in order to have possibility for realization of their values. As research results demonstrate international companies understand this situation and offer young professionals opportunities for such realization.

\subsection{Ways of motivation and strategies in local Latvian companies}

The second group of companies to be described includes local Latvian companies, which have several branches over the country and production companies. These companies exist in the market more than 15 years already. Some of these companies were fully owned by the state before and they mostly provide different services (post services, banking, logistics, processes optimization etc.) and other produce goods. In such organizations having IT department is very important due to necessity of keeping up and running technical equipment, managing databases, optimizing processes and pay special attention to security of information, but usually the work of IT professional in such organization is more invisible as if everything functions correctly, no one remembers about them: "IT departments are not so valued [..] but it is impossible to work without IT department [..]” (Ivan).

The research results allow determining two models which are used by big Latvian companies for retaining of the employees and shaping their loyalty to the company. The first model is oriented to the realization of the need of stability. This model assumes that the organization guarantees its employees stable work, which is provided by its name (brand) and reputation, official employment and regular salary payout "Bank is a serious organization, this played one of the important parts" (Ivan) and offering if not the high salary but at least promising stability and social benefits: "First of all, stability: official hiring procedure, stability, vacation. There are several social benefits. [..] I knew I will go to maternity leave with peace of mind, come back and my place will still be mine [...] stability”(Maria); “And what "bribed me”, what I assumed and it happened so in reality, they will pay in time [..] as a matter of fact, it is the basic "(Ivan), "Stability in paying salary: it is not delayed, paid before 15th every month” (Vitaliy).

As the interviews demonstrate all the above factors are important for respondents why have chosen these companies as their working place. In this case regularity and stability of salary payout are values higher than its size and keeping the work place during maternity leave period is more important that opportunity of working remotely. It is necessary to mention that flexible schedule (opportunity to come to work a bit later or leave a bit earlier) is also perceived as some kind of advantage. But this advantage is not tied with the willingness of having more freedom but with the necessity of fulfillment of family responsibilities. "It is pretty flexible working schedule because by agreement with management it is allowed to come a bit earlier or a bit later" (Ivan) and have special attitude to families with children: "[..] if someone has children, they need to take them to kindergarten. They can come a bit later and consequently leave a bit later as well" (Ivan), "For those who have families vacation is given in summer to go to the sea. It is in priority. For those without families vacation is given for a choice: autumn, winter" (Vitaliy). Married employees with children are allowed to have full vacation at once if they really need it: "I can take all vacation at once as I have done right now. On my own wish" (Alexey), "I define myself when I want to go on vacation" (Maria). However there are several restrictions which need to be taken into account as employees still have fixed 8 hours working day and sometimes face difficulties of leaving the working place during the day: "We come to the company and cannot leave easily. We need to take check passes" (Vitaliy).

Analysis of the interviews reflects that big Latvian companies promote family values which attracts people of older age, the ones who are married and have children. For such type of people traditional values are more relevant. They are afraid of losing job, of the changes and risk. In this case stability is a very significant factor in shaping loyalty. Even if the employees do not like the current job much they unlikely would like to change it.

One more tool of shaping loyalty and attractiveness in the model of stability is the provision of the dormitory for the employees of a loan for buying housing. This strategy ties employee to the company for a long time period independently on his job satisfaction. "Organization provided us with place to live. It is a dormitory" (Maria), "Company helped with noninterest loans for buying housing or a car" (Alex). In such a way employees get dependent on the company which allows it doing nothing more in order to attract or retain of professionals. 
The second model of shaping loyalty which big Latvian companies use it connected with employees' life comfort upgrade. The companies cover the costs of attending the gym, provide insurance and opportunity to visit sanatoriums, compensate kindergarten costs and also make corporate celebrations of the generally accepted holidays. "Here, where I work there is a gym. I do workout during the lunch" (Maria), "For females, for example, there is yoga class [..] for males they rent football fiend and we can come and play once a week" (Ivan); "On company anniversary we ride the boat [...] on New Year there is a tradition not only to celebrate but to make carnival” (Maria), "Anniversary of the company is celebrated and all employees go to the sea for free. And we also have New Year, also free for employees" (Alex), "It is common, but New Year celebration" (Alexey_L); "We have medical insurance, using which you can get the treatment, big range of medical services" (Ivan), "Social package includes everything [..] sanatorium in Jurmala for half-price" (Vitaliy) or partly paid kindergartens: "[..] party cover kindergarten costs, summer camp [..] different clubs for kids" (Alex_L), "On September 1st events for kids are organized, they give presents" (Ivan).

In reviewing this strategy it is possible to conclude that it looks very traditional and also is based on traditional values, giving special advantage for families with children. It is possible to assume that some traditions have moved to contemporary strategy from Soviet times like sanatoriums, family support or big celebrations.

In this case there is some inequality in the strategy and young professionals who do not have families yet or do not plan this in nearest future might be not interested in working in such organization. It can also be proved by the fact that most of the respondents - employees of these companies questioned were at age of 27-30. So very soon they will not be considered as "young" professionals and they start seeking for more financial stability meaning career growth and growth of salary as their thoughts are connected with future of their children and improvement of living conditions: "I have plans to change job for more well-paid" (Maria), . "I want to organize my own business and leave from there” (Alex_L).

As IT knowledge require constant update and IT professionals are in need of improving their qualification due to specifics of their job, unfortunately, such companies do not offer much in comparison with the international companies described above: "Not much money is given for employees to go and study, improve qualification.
Therefore you need to go for your own money [..]" (Vitaliy), "If you need to study organization can give you study vacation" (Alexey), "Courses are held very rarely" (Maria), "We have our library and access to Internet” (Alex).

All in all this strategy resembles the one described by Russian researchers I. Kozina and L. Chelgakova in their work "Corporate Youth Policy: The approach of Russian industrial enterprises", where among tendencies in Russian enterprises they name help with housing for young people and additional payouts in the beginning of the career (Kozina \& Chelgakova, 2014). They way of management in such organizations resembles the "Theory X" Douglas McGregor described as focused on control, centralized power and more authoritarian way of management. While this might satisfy workers who are put into specific life conditions (mortgage loan, little children to take care of) at some point, this might be not acceptable for younger professionals who do not have any factors in their lives which might limit their choice of the working place.

\subsection{Ways of motivation and strategies in IT sphere}

The third group of companies includes companies which operate in IT sphere so they are profile ones for IT professionals. They operate in different spheres of IT industry including Internet provider companies, service companies, companies which create IT solutions for corporate clients, programming companies and companies that work for creating different applications for smart phones and tablets. These companies might be either international or local ones and they are all famous in their sphere, several respondents point out that in its sphere of occupation the company is famous or can be called one of the market leaders: "yes, one of the [market leaders] " (Sasha), "[answering a question if it is a famous company] yes, it is [..] we have many clients [..] cannot call it a leader because there are no leaders here [..] but we are in top 5 among other companies" (Sergey). Such companies mostly employ IT professionals so it is possible to say that IT professionals are the backbone of such organizations. As industry is developing constantly they are in need of "fresh blood". For these companies it is very important for professionals to show enthusiasm and come back with fresh ideas which can bring new opportunities for this competitive business therefore the ways of motivation take this in consideration. 
In order to attract young employees these companies offer them high salary which is increased depending on the work results. Such strategy stimulates employees to do their job well and tie their career development with exactly this company. "[the terms of work fit me and I went there [... I expensively evaluate my labor and always ask for pretty big salary" (Arturs), they raise salary so employees do not leave" (Den), "until there is stability good salary, such colleague I would like to work there for a long time" (Armands).

One more important strategy of attracting and retaining of young professionals in a company are providing employees with opportunity to get a share in a business or to create their own business in the framework of the activity of the same company. "In alternative projects you need you use everything new [..] next from professional point of view there is an owner, not a programmer [..] I can become an owner in this incubation project” (Vlad), “...you can do different company inside this company [..] a subsidiary company" (Den).

The research results demonstrate that this strategy is effective for attracting ambitious young professionals who are not afraid to risk, who have or are able to generate fresh talented ideas but do not have an opportunity or resources to start their own business. Thanks to this strategy, such companies have their own market segment; they do not compete in attractiveness either with international or big Latvian companies.

It is necessary to point out that as far as possible new Latvian companies if spheres of IT also provide their employees with benefits which employees of international companies have. We can name here insurance, attending gym ("very good social package, insurance, doing sports is paid and two week vacation to any country is paid"), and opportunity for professional development and education by covering costs of different courses "Company is ready to make advances. If there are some interesting seminars, it pays. Particularly on February we had IT-conventions on UI-interface design” (Arturs), "There is an opportunity [to improve qualification] using European financing which covers $75 \%$ of educational costs” (Sergey), "Also company pays for all courses which are needed to get definite certificates, internationally acknowledged" (Sasha).

On top of that companies create convenient working environment for their employees: free luches and parking spaces free of charge, good technical equipment ("fully paid lunch, free parking[..] plus on Friday bigger budget for lunch and we order it from the restaurant"(Arturs), "No technical limits, if a person wants two monitors, he gets two monitors" (Arturs) as well as friendly atmosphere in the office ("we also get together somewhere in the out-of-doors. We get together and go for example to children's houses, give some presents. This unifies the working community" (Armands)).

However the most important difference of the modern Latvian companies from other types of companies is that they give their employees an opportunity to take part in highly-technological new projects which significantly upgrades their processional skills and promotes their competitiveness on the market; and also this influences employees' job satisfaction dramatically "We have opportunity of using new technologies on the modules [..] Programmers are interested in that because here they can use the things which appeared not long ago (Arturs)". "They offer new interesting projects which are developed not in working time but on different terms and conditions" (Vlad), "There is an opportunity to study, to get certificate" (Sergey).

Among one of the peculiarities of such companies is that their strategy is more adapted to the needs of IT specialists as on the satisfaction of the current employees and on the new employees to be attracted depends the success of the business. In order to create fresh ideas employees need to be motivated and company needs to attract new ones on a regular basis so they offer goof technical equipment, opportunity to use new software, attend courses for getting certificates later and good working atmosphere.

\section{Discussion}

Interviewing as a method of collecting data is more subjective then many quantitative methods. However the aim of the research was to find out general patterns. It is clear that justification of these patterns requires further research.

Proving the results of the research demands triangulation of methods and selecting more units for interviewing.

\section{Limitations}

The research was conducted with the small sample. This is why even though we believe that patterns are shown clearly it cannot be considered 
comprehensive and represents the general situation in IT sector. More factors such as generational and locational aspect should be considered along with bigger coverage. However small sample brings the risk that identified typology of motivations in different types of organization may be random result of a small sample.

While selecting units to study authors focused at the age of respondents and their employment to different types of organizations. It is possible that is other criteria to selecting units were applied the results could be different.

\section{Conclusions}

The results of the research demonstrated the values of employees of IT specialists and helped to chase how companies meet expectations of young IT professionals.

According o the small sample studied during the research in the IT market there are three types of companies, which differ from each other both in working conditions and in strategies of attracting, retaining young professionals and shaping their loyalty to the organization. International companies, which have their branches in Latvia, are trying to satisfy the needs of young professionals for self-expression, freedom and self-realization. They are investing in human capital by giving an opportunity to work remotely, help employees to develop their skills and improve professional qualification, whilst providing them with decent income. The goal of these companies is to make work interesting and create competitiveness in a company to motivate people to demonstrate their best qualities and strengths and also to make them interested in continuing working for this organization.

Big Latvian companies are oriented towards attracting people with different types of values. They offer their employees stable job, stable income and convenience working conditions. They are trying to create environment where employees feel their dependence from the organization and are afraid to lose their jobs.

Modern IT companies offer their employees partner relationships and opportunity to develop their careers. This shapes attachment to the company and creates desire to make this company more competitive.

Currently in Latvia there are companies which are ready to satisfy the values of both younger and older cohorts. However it is possible to assume that with time there might be a conflict between two generations which might have consequences for certain organization and for the market in general.

\section{Disclosure Statement}

Authors are required to include a statement at the end of their article to declare whether or not they have any competing financial, professional, or personal interests from other parties.

\section{References}

Alderfer, C. (1972). Existence, relatedness, and growth: Human needs in organizational settings. New York: Free Press.

Allen, D., \& May, C. (2017). Organizing practice and practicing organization: an outline of translational mobilization theory. SAGE Open, 7(2), 1-14. https://doi.org/10.1177/2158244017707993

Bidwell, M., \& Mollick, E. (2014). Shifts and ladders: Comparing the role of internal and external mobility in executive careers. Paper presented at the Academy of Management Meeting, Philadelphia, USA. https://doi.org/10.5465/ambpp.2014.92

Bourdieu, P. (1996). Distinction: A social Critique of the Judgement of Taste. Cambridge, Massachusetts: Harvard University Press. 8th printing.

Deci, E. L. (1975). Intrinsic motivation. New York, NY: Plenum. https://doi.org/10.1007/978-1-4613-4446-9

Feldman, D. C., \& Ng, T. W. H. (2007). Careers: Mobility, embeddedness, and success. Journal of Management, 33(3), 350-377. https://doi.org/10.1177/0149206307300815

Herzberg, F. (1987). One more time: How do you motivate employees. Harvard Business Review, (September-October), pp. 87-97.

Herzberg, F., Mausner, B., \& Snyderman, B. B. (2010). The motivation to work. New Brunswick: Transaction Publishers.

Hildebrandt, S., \& Eom, M. (2011). Teacher professionalization: Motivational factors and the influence of age. Teaching and Teacher Education, 27(2), 416-423. https://doi.org/10.1016/j.tate.2010.09.011

Inglehart, R., \& Welzel, Ch. (2005). Modernization, cultural change, and democracy. The Human development sequence. Cambridge: Cambridge University Press. https://doi.org/10.1017/CBO9780511790881

Ji, J., Anderson, D., \& Wu, X. (2016). Motivational factors in career decisions made by science museum educators. Adult Education Quarterly, 66(1), 21-38. https://doi.org/10.1177/0741713615609993

Kahn, W. (1990). Psychological conditions of personal engagement and disengagement at work. Academy of Management Journal, 33(4), 692-724.

Kopelman, R. E., Prottas, W. J., \& Falk, D. W. (2012). Further development of a measure of theory X and Y managerial assumptions. Journal of Managerial Issues, 24(4), 450-470.

Kozina, I., \& Chelgakova, L. (2014). Corporate Youth policy: The approach of Russian industrial enterprises. The Journal of Social Policy Studies, 12(1), 95-110. 
Lado, A. A., \& Wilson, M. C. (1994). Human resource systems and sustained competitive advantage: A competency based perspective. Academy of Management Review, 19(4), 699-727. https://doi.org/10.5465/amr.1994.9412190216

Llaci, S. (2010). Business management. Motivation. Tirane, Albania: albPAPER.

Maslow, A. (1954). Motivation and personality. New York: Harper.

McClelland, D. C., \& Burnham, H. (1976). Power is the great motivator. Harvard Business Review, (March-April), 100-109.

McGregor, D. (1960). Human side of enterprise. New York: McGraw-Hill.

Naujokaitiene, J., Tereviciene M., \& Zyudzinaite, V. (2015). Organizational support for employee engagement in Technology Enhanced Learning. SAGE Open, (October-December), 1-9.

Park, J. H., \& Choi, H. J. (2009). Factors influencing adult learners' decision to drop out or persist in online learning. Educational technology \& Society, 12, 207-217.

Pfeffer, J. (1994). Competitive advantage through people: Unleashing the power of the work force. Boston, MA: Harvard Business School Press.
Ryan, R. M., \& Deci, E. L. (2000a). Intrinsic and extrinsic motivations: Classic definitions and new directions. Contemporary Educational Psychology, 25(1), 54-67. https://doi.org/10.1006/ceps.1999.1020

Ryan, R. M., \& Deci, E. L. (2000b). Self-determination theory and facilitation of intrinsic motivation, social development, and well-being. American Psychologist, 55(1), 68-78. https://doi.org/10.1037/0003-066X.55.1.68

Shoraj, D., \& Llaci, S. (2015). Motivation and its impact on organizational effectiveness in Albanian businesses. SAGE Open, (April-June), 1-8. https://doi.org/10.1177/2158244015582229

Trigg, A. B. (2004). Deriving the engel curve: Pierre Bourdieu and the social critique of Maslow's hierarchy of needs. Review of Social Economy, 62(3) (September), 393-406. https://doi.org/10.1080/0034676042000253987

Verbruggen, M., Cooman, R. D., \& Vansteenkiste, S. (2015). When and why are internal job transitions successful? Transition challenges, hidrances, and resources influencing motivation and retention through basic needs satisfaction. Group \& Organization Management, 40(6), 744-775.

https://doi.org/10.1177/1059601115595935 